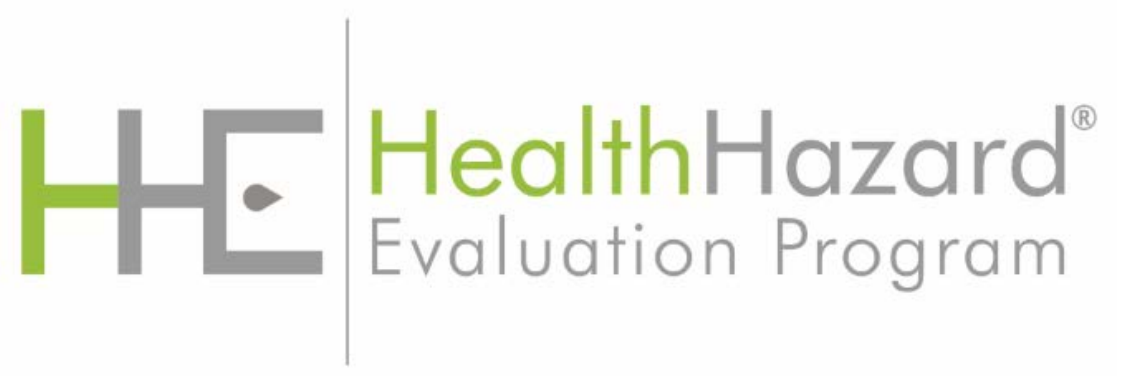

\title{
Exposure to Lead During Residential Water Line Replacement Activities
}

HHE Report No. 2019-0192-3377

J anuary 2021

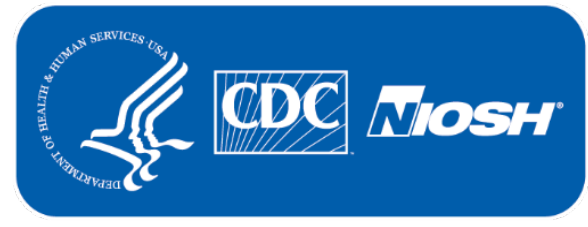




\section{Authors: $\quad$ Mark M. Methner, PhD, ClH}

\section{Marie A. de Perio, MD}

Analytical Support: Bureau Veritas North America, Inc.

Desktop Publisher: Shawna Watts

Editor: Cheryl Hamilton

Industrial Hygiene Field Assistance: Josie Ehlers, $\mathrm{PhD}$

Logistics: Donnie Booher and Kevin Moore

Keywords: North American Industry Classifiation System (NAICS) 237110 (Water and Sewer Line and Related Structures Construction), Lead, Air Sampling, Particulate, Surface Contamination, Dermal Exposure, Wipe Test, Blood Lead Levels, Ohio

\section{Disclaimer}

The Health Hazard Evaluation Program investigates possible health hazards in the workplace under the authority of the Occupational Safety and Health Act of 1970 [29 USC 669a(6)]. The Health Hazard Evaluation Program also provides, upon request, technical assistance to federal, state, and local agencies to investigate occupational health hazards and to prevent occupational disease or injury. Regulations guiding the Program can be found in Title 42, Code of Federal Regulations, Part 85; Requests for Health Hazard Evaluations [42 CFR Part 85].

\section{Availability of Report}

Copies of this report have been sent to the employer and employees. The state and local health departments and the Occupational Safety and Health Administration Regional Office have also received a copy. This report is not copyrighted and may be freely reproduced.

\section{Recommended Citation}

NIOSH [2021]. Exposure to lead during residential water line replacement activities. By Methner MM, de Perio MA. Cincinnati, OH: U.S. Department of Health and Human Services, Centers for Disease Control and Prevention, National Institute for Occupational Safety and Health, Health Hazard Evaluation Report 2019-0192-3377, https://www.cdc.gov/niosh/hhe/reports/pdfs/20190192-3377.pdf. 


\section{Main Report}

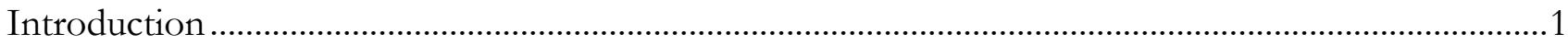

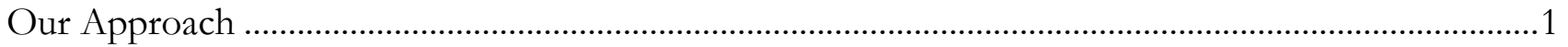

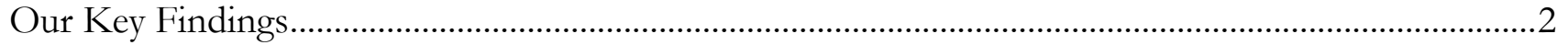

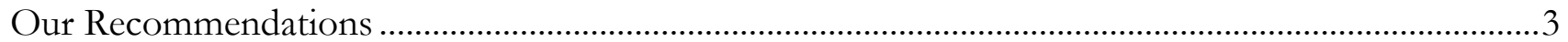

\section{Supporting Technical Information}

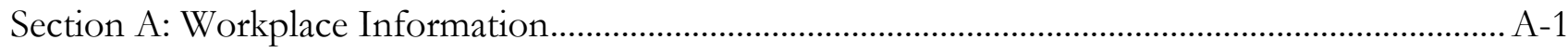

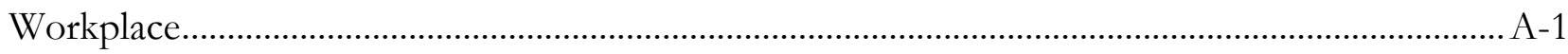

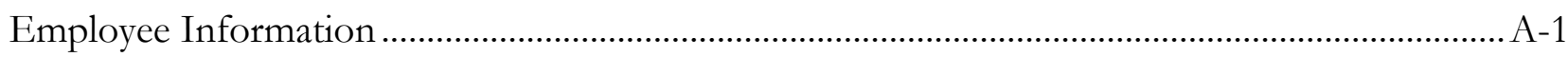

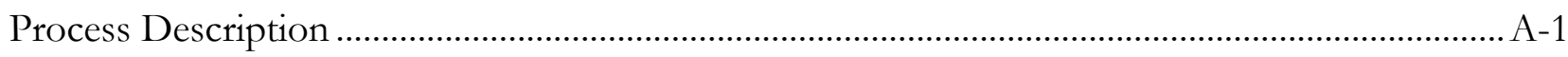

Section B: Methods, Results, and Discussion ……………………………………………..... B-1

Methods: Employee Health Assessment …………………....................................................... B-1

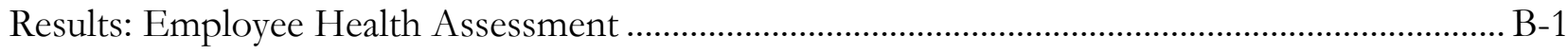

Methods: Exposure Assessment ........................................................................................ B-3

Results: Exposure Assessment ......................................................................................... B-3

Methods: Health and Safety Program and Document Review, and Observations.......................... B-4

Results: Health and Safety Program and Document Review, and Observations............................ B-4

Discussion ................................................................................................................... B-5

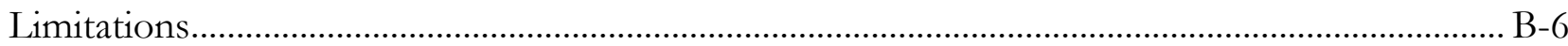

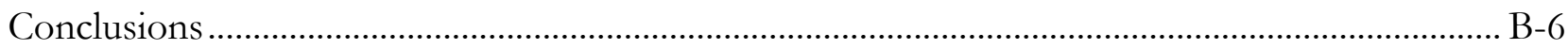

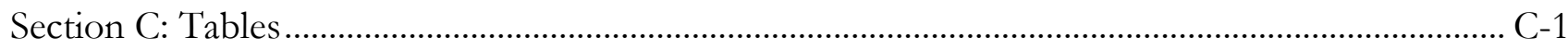

Section D: Occupational Exposure Limits .............................................................................. D-1

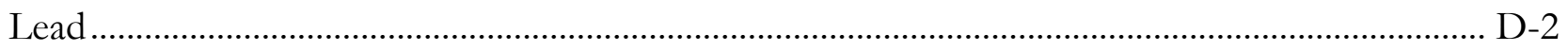

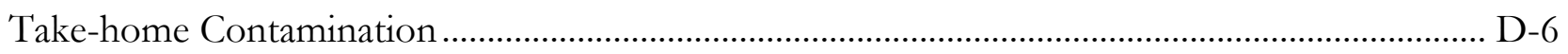

Section E: References ............................................................................................................ E-1 
This page left intentionally blank 


\section{Introduction}

\section{Request}

An employer from a city water department requested a health hazard evaluation to address concerns about lead exposure among crews replacing lead water lines servicing residential homes. This occurred after two employees received blood tests indicating elevated lead levels. In response to these findings, the employer implemented some measures to minimize lead exposures among employees.

\section{Workplace}

Replacing a lead residential service water line involved excavating soil and creating a trench using a backhoe and shovels. Workers shut off the water supply to the home and disconnected or cut the lead service line. They connected a new copper service line to the old lead line and pulled the new line through the soil. Then they removed the old lead line and reconnected the new copper line to the water main line. Last, they tested for leaks.

Sometimes, a steel cable was threaded through the inside of the lead line and pulled, using the backhoe bucket, to remove the line. If the lead line collapsed or was partially compressed, a thin polyester rope (string) was blown through one end using compressed air until it exited the other end. The rope was then attached to the steel cable and pulled through until the line was removed and the new copper line was in place. Soil and gravel were then replaced and the surface repaired. A licensed plumbing contractor made the final connection to the home.

We performed an exposure assessment for all eight active lead service line replacement workers across two work crews. These employees normally work an 8-hour shift, Monday through Friday.

To learn more about the workplace, go to Section A in the Supporting Technical Information

\section{Our Approach}

We visited worksites in July and September 2019. In July we observed the work processes involved in replacing the lead lines and in September, we conducted the exposure assessment. While there were nine lead service line replacement workers assigned to the two crews doing this work, eight (referred to as "active workers") performed the lead service line replacement work during our evaluation. We completed the following activities during our evaluation:

- Conducted confidential medical interviews with all nine employees and two supervisors.

- Collected personal air samples for lead on all eight active employees.

- Conducted colorimetric wipe sampling for lead on the hands of all eight active employees before and after each water line replacement job.

- Wiped the inside surfaces of one randomly selected work glove worn by each active worker. 
- Wiped different surfaces inside both old and new work trucks, as well as surfaces in different areas at the main pump station (e.g., worker desk surface, lockers in changing room, refrigerator handle, etc.).

- Determined whether lead particulate was expelled from the old lead pipe after the process of running a steel wire through the inside of the pipe and using compressed air to blow a string through the pipe.

To learn more about our methods, go to Section B in the Supporting Technical Information

\section{Our Key Findings}

\section{Some employees had high blood lead levels}

- Before our evaluation, two of nine employees were found to have elevated blood lead levels (BLLs) by their personal physicians in May 2019. Their BLLs were 5 micrograms per deciliter $(\mu \mathrm{g} / \mathrm{dL})$ and $6 \mu \mathrm{g} / \mathrm{dL}$. All nine employees then underwent BLL testing through the employer's Employee Health Service between May 2019 and June 2019. Eight employees had a BLL of less than $5 \mu \mathrm{g} / \mathrm{dL}$. One employee had an elevated BLL of $5.7 \mu \mathrm{g} / \mathrm{dL}$ and was one of the employees found to have an elevated BLL by their personal physician.

- The company had a written lead monitoring and control program, a hazard communication program, and a job-hazard analysis for tasks associated with lead line replacement.

- Some employees wore respirators incorrectly.

- None of the air sampling results were above the occupational exposure limit for lead (50 micrograms per cubic meter).

\section{Lead was present on employee hands and work gloves}

- We detected lead on the hands of two employees who handled the lead pipe during removal activities. We also detected lead on the inside of some work gloves after the job was completed. We observed that some workers did not wear nitrile gloves underneath their work gloves when handling lead pipe.

\section{Lead was found on surfaces inside trucks and in the locker room}

- We detected lead on some surfaces inside the old and new work trucks. We also detected lead on the handles of two lockers inside the locker room at the pump station. No lead was detected on the surface samples collected in the office area at the pump station.

To learn more about our results, go to Section B in the Supporting Technical Information 


\section{Our Recommendations}

The Occupational Safety and Health Act requires employers to provide a safe workplace.

Benefits of Improving Workplace Health and Safety:
个 Improved worker health and well-being
T Enhanced image and reputation
个 Better workplace morale
$\uparrow$ Superior products, processes, and services
$\uparrow$ Easier employee recruiting and retention
$\uparrow$ May increase overall cost savings

The recommendations below are based on the findings of our evaluation. For each recommendation, we list a series of actions you can take to address the issue at your workplace. The actions at the beginning of each list are preferable to the ones listed later. The list order is based on a well-accepted approach called the "hierarchy of controls." The hierarchy of controls groups actions by their likely effectiveness in reducing or removing hazards. In most cases, the preferred approach is to eliminate hazardous materials or processes and install engineering controls to reduce exposure or shield employees. Until such controls are in place, or if they are not effective or practical, administrative measures and personal protective equipment might be needed. Read more about the hierarchy of controls at https://www.cdc.gov/niosh/topics/hierarchy/.

We encourage the company to use a health and safety committee to discuss our recommendations and develop an action plan. Both employee representatives and management representatives should be included on the committee. Helpful guidance can be found in "Recommended Practices for Safety and Health Programs" at https://www.osha.gov/shpguidelines/index.html.

\section{Recommendation 1: Reduce employees' exposure to lead through improved work practices}

Why? Lead is considered toxic to all organ systems and serves no useful purpose in the body. Overexposure or unnecessary exposure can contribute to long-term lead poisoning. Employees exposed to lead may not have symptoms, or they may have nonspecific symptoms such as headache, joint and muscle aches, weakness, and fatigue. These can worsen over time and could be associated with the following:

- More sick leave

- Job loss

- Lower quality of life

We found that two employees had elevated blood lead levels in May 2019. The employer had implemented multiple measures to minimize lead exposures among employees prior to our visit in September. Although personal airborne lead exposures were below occupational exposure limits, we 
found lead on employees' hands after the completion of the job and on other surfaces such as inside the trucks and inside the locker room.

How? At your workplace, we recommend these specific actions:

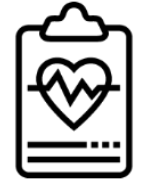

\section{Improve surveillance, training, and work practices}

- Continue to monitor blood lead levels at least annually.

- Continue to provide lead health hazard training upon hire and annually.

- Ensure no employee is present in the excavation trench when compressed air is used to blow the string through the pipe.

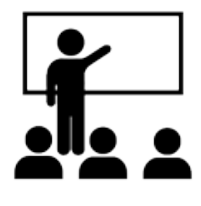

\section{Improve personal protective equipment use and training}

- Provide refresher training on proper respirator wear, maintenance, and storage.

- Change out work gloves more frequently, especially if they are worn or heavily soiled.

- Ensure nitrile gloves are available on all trucks and worn by all employees underneath their work gloves.

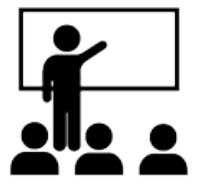

\section{Implement procedures and further train employees to keep their hands} clean and free of lead

- After all work tasks, and specifically prior to entering the truck, implement procedures for hand and tool cleaning.

- Ensure lead removal wipes are available on all trucks and make sure employees use them to clean their hands after work is completed and before eating or drinking.

- Provide lead removal soap in the locker room.

\section{Improve cleaning procedures to reduce lead exposure}

- Develop a schedule to clean "high contact" surfaces (e.g., locker handles, doorknobs, truck cab surfaces, tools, etc.) using either lead removal wipes or lead removal soap.

Recommendation 2: Consider purchasing colorimetric wipe test kits and periodically test hands, surfaces, and tools for lead

Why? Periodic tests will help identify potential sources of exposure and provide an indicator of the effectiveness of cleaning efforts and personal protective equipment usage. 


\section{Supporting Technic al Information}

Exposure to Lead During Residential Water Line Replacement Activities

HHE Report No. 2019-0192-3377

J a nuary 2021 


\section{Section A: Workplace Information}

\section{Workplace}

These employees worked in two crews replacing lead water pipes that serviced homes. The crews home base is the City water pumping station where vehicles, equipment, supplies, offices and a locker room are housed.

\section{Employee Information}

Number of employees at time of evaluation: 11 total employees, with 8 active employees working on line replacement

Length of shift: typically 8 hours, Monday through Friday

Mean age: 50 years, range: $34-58$ years

Mean tenure at job: 11 years (range: 2-30 years) working with employer, 19 months (range: 14 24 months) working on the crew

History of Issue at Workplace: In May 2019, two employees visited their personal physicians and discovered their BLLs were elevated. The employer implemented measures to minimize lead exposures among employees prior to our visit in September 2019.

\section{Process Description}

Replacing a lead residential service water line involved the following steps:

- Excavate soil and create trenches using a backhoe and shovels. Use the trenches to find the connections between the main line, the curb stop (shut off valve), and the home.

- Shut off water supply to the home and disconnect/cut the lead service line.

- Connect a new copper service line to the old lead line and pull the line through the soil. Disconnect and remove the old lead line and reconnect the new copper line to the water main line. Test for leaks. On occasion, a steel cable is threaded through the inside of the lead line and pulled, using the backhoe bucket, to remove the line. If the lead line is collapsed or partially compressed, a thin polyester rope (string) is blown through one end using compressed air until it exits the other end of the line. The rope is then attached to the steel cable and pulled through and the process is repeated until the line is removed and a new copper line is in place.

- A licensed plumbing contractor makes the final connection to the home.

- When the line replacement is complete, soil and gravel are backfilled into each excavation and the road surface/curb/sidewalk is repaired. 


\section{Section B: Methods, Results, and Discussion}

\section{Methods: Employee Health Assessment}

\section{Employee Health Records}

We reviewed relevant medical records on each lead service line replacement employee from the employer's Employee Health Service. Records for each employee included results from a medical surveillance examination from May 2019 through June 2019, which contained a medical history questionnaire, physical examination, a laboratory report including BLLs, and a spirometry report. An elevated BLL was defined as $\geq 5 \mu \mathrm{g} / \mathrm{dL}$, which is considered the reference blood lead level for adults [CSTE 2015]. This case definition is consistent with the current case definitions used by the National Institute for Occupational Safety and Health (NIOSH) Adult Blood Lead Epidemiology \& Surveillance (ABLES) program, the Council of State and Territorial Epidemiologists (CSTE), and the Centers for Disease Control and Prevention (CDC) National Notifiable Diseases Surveillance System [CDC 2015, 2016; CSTE 2015].

\section{Confidential Medical Interviews}

During our visits in September 2019, we invited all nine lead service line replacement employees and two supervisors to participate in confidential, medical interviews. During the interviews, we discussed pertinent medical history, work history and practices including job tasks, use of personal protective equipment (PPE), and hygiene practices, and nonoccupational exposures to lead.

\section{Results: Employee Health Assessment}

\section{Employee Health Records}

We reviewed relevant medical records for all nine lead service line replacement employees. Two employees had a BLL ordered by their personal physician prior to a BLL evaluation through the employer. One employee had a BLL of $5 \mu \mathrm{g} / \mathrm{dL}$, and the second employee had a BLL of $6 \mu \mathrm{g} / \mathrm{dL}$ in May 2019. All nine employees had a BLL obtained through the employer's Employee Health Service between May 2019 and June 2019. Five employees had BLLs of < $2.0 \mu \mathrm{g} / \mathrm{dL}$; three employees had BLLs ranging 2.6-4.6 $\mu \mathrm{g} / \mathrm{dL}$. One employee had an elevated BLL of $5.7 \mu \mathrm{g} / \mathrm{dL}$ and was one of the employees found to also have an elevated BLL by their personal physician.

According to employee health records, three employees reported a previous diagnosis of hypertension. On exam, three employees were found to have an elevated blood pressure ( $>120 / 80)$; two of those had a previous diagnosis of hypertension. One employee reported a previous diagnosis of anemia. None of the employees reported a diagnosis of kidney disease. Two employees had a slightly elevated creatinine, which is a measure of kidney function. Two employees had a low hemoglobin result (12.5 grams per deciliter $[\mathrm{g} / \mathrm{dL}]$ and $13.5 \mathrm{~g} / \mathrm{dL}$, reference range: $13.7-17.5 \mathrm{~g} / \mathrm{dL}$ ), which is suggestive of mild anemia. These two employees with the low hemoglobin had the elevated BLLs identified by their personal physicians. All nine employees had normal spirometry results.

B-1 


\section{Confidential Medical Interviews}

We interviewed all nine lead service line replacement employees and two supervisors. Ten were male; one was female. The median age was 50 years (range: 34-58 years). The median amount of time worked on the crew was 19 months (range: 14-24 months), and the median amount of time worked for the employer was 11 years (range: 2-30 years). The 11 interviewed employees included truck drivers $(\mathrm{n}=2)$, maintenance workers $(n=2)$, machine equipment operators $(n=2)$, valve operator $(n=1)$, crew leader $(n=2)$, and supervisors $(n=2)$. Both supervisors reported spending very little of their work time on the job sites. One employee was on light duty because of an injury and had not worked on a job site since resumption of lead service line replacement work. Therefore, eight employees were considered active employees engaged in lead line replacement work.

Job tasks since July 2019, reported by interviewed employees are shown in Table C1. Over the same period, six employees reported working in the water main branch trench (under the street surface), and six employees reported working in the curb stop trench (near the sidewalk). Five interviewed employees reported not working in either trench.

Regarding PPE use since July 2019, six of the eight employees reported sometimes wearing filtering facepiece respirators (N95 style) when at the job site. Reported activities during which respirators were worn included when cutting or filing lead and when saw cutting asphalt on the street. The two employees who reported never wearing respirators when at the job site reported that they had not worked on job tasks where respirator use was necessary. Five of eight active employees reported always wearing work gloves when at the job site while three reported sometimes wearing work gloves. However, the three reporting sometimes wearing work gloves also reported using work gloves when digging, cutting, and handling the lead pipe. Seven employees reported wearing the nylon mesh gloves with nitrile foam palm and fingers; the other employee reported wearing leather gloves. Three employees reported wearing nitrile gloves underneath their nylon mesh gloves. Employees who stated they used nylon mesh gloves reported changing them as frequently as one to three times during a shift.

Since July 2019, all eight employees reported always changing their clothes at the end of the work shift and reported always changing out of their boots before leaving work. All eight reported eating or drinking while on the jobsite, and one employee reported smoking during the work shift. Hand hygiene practices reported by employees since July 2019, are displayed in Table C2. More employees reported always washing hands at the job site than always using lead removal handwipes at the job site.

Interviewed employees were also asked about nonoccupational exposures to lead. None of the interviewed employees reported activities that may pose increased risk for exposures to lead, including recreational shooting, making or reloading ammunition, collecting lead-containing material for recycling, making leaded fishing weights or lures, or making pottery or ceramics that use glazes. One interviewed employee reported remodeling or renovating an old home, and two reported doing their own automobile body work or handling car batteries.

None of the interviewed employees reported having a diagnosis of hypertension, kidney disease, fertility problems, or anemia since starting work on the lead service line replacement crew. In addition, none of the interviewed employees reported any of the following symptoms (in the prior three months) that 
could be consistent with excess exposure to lead: problems with balance, numbness or tingling of the hands and feet, unusual joint pain, severe fatigue, constipation, and problems with concentration.

\section{Methods: Exposure Assessment}

\section{Personal Air Sampling}

We collected task-based personal air samples on the eight active employees. The tasks associated with one complete line replacement took about 3 hours. The remainder of the workday involved other tasks such as moving equipment back to the shop at the pump station, restocking supplies, and office duties. Based on our observations, these other tasks did not pose a potential for lead exposure. We analyzed the air samples for lead using NIOSH Method 7303. The current Occupational Safety and Health Administration (OSHA), NIOSH, and American Conference of Governmental Industrial Hygienists (ACGIH) occupational exposure limit (OEL) is 50 micrograms per cubic meter $\left(\mu \mathrm{g} / \mathrm{m}^{3}\right)$ for lead in air.

\section{Hand and Surface Wipe Sampling}

We collected personal handwipe samples for lead using a colorimetric method (Full Disclosure ${ }^{\circledR}$ ) on the eight active employees immediately upon arrival at the pump station before they started their shift and upon completion of the line replacement work. We also wiped the inside surface of a randomly selected work glove worn by each employee. In addition, we collected surface wipe samples on a variety of surfaces within the truck cab (new and old trucks), tool bins and shelves, locker handles, desktops, and a conference room tabletop. This wipe sampling method shows a color change in the presence of lead with a minimum detection limit of 18 micrograms $(\mu \mathrm{g})$ per wipe.

Before collecting a wipe sample, the NIOSH investigator put on a clean pair of nitrile gloves. The employees were then handed a clean premoistened Ghost Wipe ${ }^{\mathrm{TM}}$ and asked to wipe the front and back of their hands and between their fingers with this wipe for 1 minute. We asked them not to wipe past their wrists. After employees were finished wiping their hands, we had them place the used wipe in a clean, screw-top container for transport to the NIOSH lab. For other surface wiping, we used a similar collection technique. We put on a clean pair of nitrile gloves and then used a clean premoistened Ghost Wipe $^{\text {TM }}$ to collect the surface wipe sample, following NIOSH Method 9100. We used a 100-squarecentimeter $\left(100 \mathrm{~cm}^{2}\right)$ disposable template to outline the surface areas that were sampled. For non-flat surfaces (e.g., steering wheel, door handle, etc.), we wiped an estimated area of $100 \mathrm{~cm}^{2}$.

Neither NIOSH nor OSHA has OELs for lead on hands or surfaces. The OSHA lead standard requires that all surfaces be maintained as free as practicable of accumulations of lead [CFR 2021].

\section{Results: Exposure Assessment}

\section{Personal Air Sampling}

The results from the air samples we collected are shown in Table C3. None of the results were above the OEL for lead $\left(50 \mu \mathrm{g} / \mathrm{m}^{3}\right)$. Task-based air sampling results ranged from none detected (ND, which is below $0.6 \mu \mathrm{g} / \mathrm{m}^{3}$ ) to $7.1 \mu \mathrm{g} / \mathrm{m}^{3}$. We also calculated an 8-hour time-weighted-average (TWA) exposure value by assuming no airborne exposure to lead occurred during the time away from the job. This calculation yielded values that ranged from ND to $3.2 \mu \mathrm{g} / \mathrm{m}^{3}$. 


\section{Handwipes}

Results of wipe samples collected from the hands and inner work glove surfaces are in Table C4. None of the employee's preshift handwipes showed lead contamination prior to starting work. However, two employees (maintenance worker and crew leader) showed lead contamination inside their gloves and on their hands after the work was completed. Inner glove surface values ranged from ND $(<18 \mu \mathrm{g})$ to $140 \mu \mathrm{g}$ per wipe while handwipe sample values ranged from ND to $350 \mu \mathrm{g}$ per wipe. This finding occurred despite employees wearing nitrile gloves underneath work gloves. A plausible explanation for finding lead on the hands despite wearing nitrile gloves is that these workers may have touched contaminated hand tools or other contaminated surfaces prior to putting on the nitrile gloves. Another possible reason is that the workers may have inadvertently wiped potentially contaminated skin above the wrist when taking the handwipe sample. It is also possible that because of the hot weather conditions when employees were working, sweat ran down their forearms (which may have been contaminated with lead because they wore short sleeve shirts) and ended up under the nitrile gloves.

\section{Surface Wipes}

Surface wipe sample results, collected from a variety of surfaces, are in Table C5. Five of the 14 surfaces we sampled across two days showed evidence of lead contamination. We measured detectable amounts of lead (> $>\mu \mathrm{g}$ ) on the following surfaces: driver side inside door handle (new truck), tool shelf inside truck box (new and old trucks), and the handles on two different lockers inside the locker room. The highest level on a surface wipe sample $\left(1,400 \mu \mathrm{g} / 100 \mathrm{~cm}^{2}\right)$ was collected from a tool bin shelf on the new truck.

One additional test we conducted involved sampling the air exiting a lead pipe while employees used compressed air to blow a string through the pipe. This test, which used wipe sampling media held approximately 4 inches away from the exit side of the lead pipe to capture ejected lead particulate, produced a sample result of approximately $8,900 \mu \mathrm{g}$ of lead.

\section{Methods: Health and Safety Program and Document Review, and Observations}

We reviewed the employer's written lead hazard control plan, hazard communication program, and jobhazard analyses for tasks associated with lead line replacement. We also learned about measures that the employer implemented to minimize employees' exposures to lead. During our visits in July 2019 and September 2019, we observed work practices and procedures of the eight employees actively performing various tasks during lead service line replacement.

\section{Results: Health and Safety Program and Document Review, and Observations}

The employer had a written lead hazard control plan, hazard communication program, and respiratory protection program that included fit testing. The hazard control plan contained information on the health effects of lead exposure and a job-hazard analysis for each task associated with lead line replacement. The hazard communication plan also described health effects of lead exposure and included information about routes of exposure and PPE to be worn while performing tasks. We learned about measures the employer had implemented prior to our visit to minimize lead exposures among employees. These included training employees on lead hazards, providing medical surveillance of employees, providing lead removal wipes on service trucks, and the new work practice of having the 
employee vacate the curb stop trench when compressed air is used to blow the "string" through the pipe. The employer had also provided a uniform laundry service for the lead service line replacement crews.

During our visits in July 2019, we observed two employees wearing respirators incorrectly. For example, on the first day of our site visit, we observed an employee working in a shallow excavation trench wearing a half-mask elastomeric respirator equipped with P100 cartridges. However, the bottom strap of the respirator was not attached and positioned around the back of their neck. On the second day, we observed one employee wearing an N95 filtering facepiece respirator with the straps positioned over the top of their hardhat. Straps worn incorrectly will affect the seal formed between the facial skin and the respirator and reduce the protection afforded by the respirator.

We also observed that some work gloves (nylon mesh with nitrile-coated palms and fingers) worn by employees when handling lead pipe were heavily soiled and could be a potential source of lead contamination on the skin. In addition, we observed that some workers did not wear nitrile gloves underneath their work gloves when handling lead pipe.

During our visit in September 2019, we observed work processes, practices, and workplace conditions at two lead water line replacement job sites. All crew members wore work gloves (nylon mesh with nitrile-coated palms and fingers) at the job sites. We also observed that the work gloves became heavily soiled. In addition, we observed that some workers did not wear nitrile gloves underneath their work gloves when handling lead pipe.

\section{Discussion}

Two employees were found to have elevated BLLs in May 2019. No additional employees were found to have elevated BLLs on subsequent testing performed by the employer. None of the interviewed employees reported having any health problems consistent with acute or chronic lead exposure. The employer implemented multiple measures to minimize lead exposures to employees, including training of employees on lead hazards, providing medical surveillance of employees, and providing lead removal wipes on service trucks so employees could decontaminate their hands.

Our evaluation results suggest that, although airborne lead exposures are below the OEL for lead, other work practices and routes of exposure may contribute to elevated BLLs. Many of the employees that we tested had detectable lead on their hands after completing the line replacement work. We learned about inconsistent glove use (both nitrile and work gloves), hand hygiene, and use of lead removal wipes during the interviews. Inconsistent glove use and failing to clean their hands in the field with lead removal wipes before eating, drinking, or smoking can result in lead ingestion.

We found lead on various surfaces in the trucks that could contribute to exposure if the employee contacted them when not wearing gloves. We found lead present on the inside surface of work gloves, which could also contribute to exposure. Finally, the task of using compressed air to blow a string through the lead piping produced a large amount of lead aerosol being ejected from the pipe and could pose an exposure risk to an employee if they were positioned near the pipe opening during this task. Based on observations and sampling, specific job titles, such as crew leader and maintenance worker, appear to have a higher potential for exposure via all routes than other job titles. These particular job 
titles performed tasks that involved handling the lead pipe more frequently than the other job titles (e.g., truck driver or backhoe operator). However, these other job titles may be exposed while occasionally assisting others (e.g., assisting in cutting lead pipe into manageable lengths, manually pulling pipe through soil, and putting tools away after job is completed).

\section{Limitations}

Our evaluation had some limitations. First, industrial hygiene sampling can only document exposures on the days of sampling in the locations sampled. These results may not be representative of conditions during other days. Second, we could not ascertain the exact reasons the two employees had elevated BLLs. The employer had already implemented multiple exposure reduction measures prior to our visit in September. We did not observe work practices and conditions prior to these changes, and we did not ask employees about their previous work practices. Third, we did not perform clinical examinations to diagnose any lead-related medical conditions, although we reviewed relevant medical records and used standardized questions to assess lead-related symptoms during our semi-structured medical interviews.

\section{Conclusions}

Two employees were found to have elevated BLLs in May 2019. While the employer had implemented multiple measures to minimize lead exposures to employees, based on our evaluation results in September 2019, there appears to be opportunities for potential lead exposure among employees during residential water line replacement activities. All air samples were below the OEL for lead; however, we found lead on various surfaces and on the hands of some employees. Specific job titles such as crew leader and maintenance worker appear to have a higher potential for exposure via all routes than other job titles. Our findings highlight the importance of glove use, hand hygiene, and routine cleaning of surfaces. 


\section{Section C: Tables}

Table C1. Job tasks reported by interviewed employees since July 2019

\begin{tabular}{ll}
\hline Job task & $\begin{array}{c}\text { Number reporting job task } \\
\mathrm{n}=11\end{array}$ \\
\hline Drive truck & 6 \\
Drive backhoe & 3 \\
Cut asphalt & 5 \\
Excavate main branch & 6 \\
Excavate curb stop & 7 \\
Hand dig to locate lead service line & 7 \\
Shape lead connection by sanding or filing & 2 \\
Prep wire rope prior to threading through lead line & 7 \\
Manually thread wire rope through lead line & 6 \\
Use compressed air to blow string through line & 3 \\
Cut lead service line with PVC shear/cutter & 6 \\
Remove cut segments of lead line from wire rope & 7 \\
Load pieces of cut lead line into backhoe bucket & 8 \\
Transport cut lead line to Main Station in backhoe & 3 \\
Dispose of cut lead line at Main Station & 5 \\
\hline
\end{tabular}


Table C2. Hand hygiene practices reported by active employees since July 2019

\begin{tabular}{lc}
\hline Practice & $\begin{array}{c}\text { Number reporting } \\
\mathrm{n}=8\end{array}$ \\
\hline Wash hands before eating, drinking, or smoking on each work shift & 2 \\
Always & 6 \\
Sometimes & \\
Wash hands after conclusion of work at job site & 7 \\
Always & 1 \\
Sometimes & \\
Use lead removal handwipes before eating, drinking, or smoking on & \\
each work shift & 3 \\
Always & 2 \\
Sometimes & 3 \\
Never & \\
Use lead removal handwipes before conclusion of work at job site & 4 \\
Always & 2 \\
Sometimes & 2 \\
Never & \\
\hline
\end{tabular}


Table C3. Task-based air samples for lead in micrograms per cubic meter of air $\left(\mu \mathrm{g} / \mathrm{m}^{3}\right)$

\begin{tabular}{|c|c|c|c|c|}
\hline Day & Job title & $\begin{array}{l}\text { Sampling time } \\
\text { (minutes) }\end{array}$ & $\begin{array}{c}\text { Task-based } \\
\text { concentration } \\
\left(\mu \mathrm{g} / \mathrm{m}^{3}\right)\end{array}$ & 8-hour TWA* \\
\hline \multirow[t]{4}{*}{1} & Maintenance worker & 191 & 7.1 & 2.8 \\
\hline & Truck driver & 189 & 7.1 & 2.8 \\
\hline & Equipment operator (backhoe) & 189 & ND† & ND \\
\hline & Crew leader & 189 & 8.2 & 3.2 \\
\hline \multirow[t]{4}{*}{2} & Maintenance worker & 172 & 3.5 & 1.3 \\
\hline & Truck driver & 166 & $(1.1) \ddagger$ & 0.4 \\
\hline & Equipment operator (backhoe) & 180 & ND & ND \\
\hline & Crew leader & 177 & ND & ND \\
\hline \multicolumn{3}{|c|}{ ACGIH Threshold Limit Value } & & 50 \\
\hline \multicolumn{3}{|c|}{ NIOSH Recommended exposure limit } & & 50 \\
\hline \multicolumn{3}{|c|}{ OSHA Permissible exposure limit } & & 50 \\
\hline
\end{tabular}

* Note: the 8-hour TWA was calculated using the task-based exposure concentration and assuming zero exposure for the remainder of the day because workers left the jobsite.

$\dagger \mathrm{ND}=$ none detected; value was below the minimum detectable concentration (MDC) of $0.6 \mu \mathrm{g} / \mathrm{m}^{3}$. $\ddagger$ Values in parentheses indicate quantities that were between the MDC and the minimum quantifiable concentration (MQC) of $1.7 \mu \mathrm{g} / \mathrm{m}^{3}$.

Table C4. Wipe samples of hand and inner surface of work gloves

\begin{tabular}{ccccc}
\hline Day & Job title & $\begin{array}{c}\text { Preshift hands } \\
(+/-)^{*}\end{array}$ & $\begin{array}{c}\text { Inside surface of } \\
\text { work gloves } \\
(+/-)[\mu \mathrm{g}]\end{array}$ & $\begin{array}{c}\text { Post-shift hands } \\
(+/-)[\mu \mathrm{g}]\end{array}$ \\
\hline 1 & Maintenance worker & - & $+[140]$ & $+[350]$ \\
Truck driver & - & - & - \\
& Equipment operator (backhoe) & - & - & - \\
Crew leader & - & $+[60]$ & $+[200]$ \\
\hline 2 & Maintenance worker & - & $+[110]$ & $+[190]$ \\
& Truck driver & - & - & - \\
& Equipment operator (backhoe) & - & - & - \\
& Crew leader & - & $+[32]$ & $+[250]$ \\
\hline
\end{tabular}

* A positive ( + is positive and - is negative) color change on a wipe sample indicates the presence of lead above the limit of detection of the sampling method $(18 \mu \mathrm{g})$. Only positive samples were quantified, and those values appear in brackets in units of $\mu \mathrm{g}$.

Note: there are no exposure limits for lead on hands or inner glove surfaces. The information in this table is intended to serve as an indicator of whether lead was present on these surfaces and the approximate quantity on that sample. 
Table C5. Surface wipe samples in micrograms per 100 square centimeters $\left(\mu \mathrm{g} / 100 \mathrm{~cm}^{2}\right)$

\begin{tabular}{cccc}
\hline Day & Location & Positive $(+)$ or Negative $(-)^{\star}$ & Amount $\left(\mu \mathrm{g} / 100 \mathrm{~cm}^{2}\right) \dagger$ \\
\hline 1 & Driver side door handle (new truck) & + & 51 \\
& Passenger side dashboard (new truck) & - & - \\
Truck box tool shelf (new truck) & + & 1,400 \\
Outer tool bin latch handle (new truck) & - & - \\
\hline 2 & - & 130 \\
Struck box tool shelf (old truck) & + & - \\
Passenger side dashboard (old truck) & - & - \\
Driver side door handle (old truck) & - & 20 \\
Clothes Locker handle \#1 (main office) & + & 52 \\
Clothes Locker handle \#7 (main office) & + & - \\
Office cubicle desktop (main office) & - & - \\
Office cubicle desktop (main office) & - & - \\
Lunch table (main office) & - & - \\
Refrigerator handle (main office) & - & -
\end{tabular}

* A positive color change on a wipe sample indicates the presence of lead above the limit of detection of the sampling method $(18 \mu \mathrm{g})$. Only positive samples were quantified.

† We used a disposable 10-by-10 centimeter cardboard template to demarcate a $100 \mathrm{~cm}^{2}$ area for taking samples from flat surfaces. For irregularly shaped surfaces (e.g., door handle), we wiped an estimated $100 \mathrm{~cm}^{2}$ area.

Note: there are no exposure limits for lead on surfaces in the workplace. The information in this table is intended to serve as an indicator of whether lead was present on a surface that an employee could potentially contact, and the approximate quantity of lead on that surface within the boundaries of the template used to demarcate the sample collection area. 


\section{Section D: Occupational Exposure Limits}

NIOSH investigators refer to mandatory (legally enforceable) and recommended OELs for chemical, physical, and biological agents when evaluating workplace hazards. OELs have been developed by federal agencies and safety and health organizations to prevent adverse health effects from workplace exposures. Generally, OELs suggest levels of exposure that most employees may be exposed to for up to 10 hours per day, 40 hours per week, for a working lifetime, without experiencing adverse health effects.

However, not all employees will be protected if their exposures are maintained below these levels. Some may have adverse health effects because of individual susceptibility, a preexisting medical condition, or a hypersensitivity (allergy). In addition, some hazardous substances act in combination with other exposures, with the general environment, or with medications or personal habits of the employee to produce adverse health effects. Most OELs address airborne exposures, but some substances can be absorbed directly through the skin and mucous membranes.

Most OELs are expressed as a TWA exposure. A TWA refers to the average exposure during a normal 8- to 10-hour workday. Some chemical substances and physical agents have recommended short-term exposure limits (STEL) or ceiling values. Unless otherwise noted, the STEL is a 15-minute TWA exposure. It should not be exceeded at any time during a workday. The ceiling limit should not be exceeded at any time.

In the United States, OELs have been established by federal agencies, professional organizations, state and local governments, and other entities. Some OELs are legally enforceable limits; others are recommendations.

- OSHA, an agency of the U.S. Department of Labor, publishes permissible exposure limits [29 CFR 1910 for general industry; 29 CFR 1926 for construction industry; and 29 CFR 1917 for maritime industry] called PELs. These legal limits are enforceable in workplaces covered under the Occupational Safety and Health Act of 1970.

- NIOSH recommended exposure limits (RELs) are recommendations based on a critical review of the scientific and technical information and the adequacy of methods to identify and control the hazard. NIOSH RELs are published in the NIOSH Pocket Guide to Chemical Hazards [NIOSH 2007]. NIOSH also recommends risk management practices (e.g., engineering controls, safe work practices, employee education/training, PPE, and exposure and medical monitoring) to minimize the risk of exposure and adverse health effects.

- Another set of OELs commonly used and cited in the United States include the threshold limit values or TLVs, which are recommended by the ACGIH. The ACGIH TLVs are developed by committee members of this professional organization from a review of the published, peerreviewed literature. TLVs are not consensus standards. They are considered voluntary exposure guidelines for use by industrial hygienists and others trained in this discipline "to assist in the control of health hazards" [ACGIH 2021]. 
Outside the United States, OELs have been established by various agencies and organizations and include legal and recommended limits. The Institut für Arbeitsschutz der Deutschen Gesetzlichen Unfallversicherung (Institute for Occupational Safety and Health of the German Social Accident Insurance) maintains a database of international OELs from European Union member states, Canada (Québec), Japan, Switzerland, and the United States. The database, available at https://www.dguv.de/ifa/gestis/gestis-stoffdatenbank/index-2.jsp, contains international limits for more than 2,000 hazardous substances and is updated periodically.

OSHA (Public Law 91-596) requires an employer to furnish employees a place of employment free from recognized hazards that cause or are likely to cause death or serious physical harm. This is true in the absence of a specific OEL. It also is important to keep in mind that OELs may not reflect current health-based information.

When multiple OELs exist for a substance or agent, NIOSH investigators generally encourage employers to use the lowest OEL when making risk assessment and risk management decisions.

\section{Lead}

Inorganic lead is a naturally occurring, soft metal that has been mined and used in industry since ancient times. It comes in many forms (e.g., lead acetate, lead chloride, lead chromate, lead nitrate, lead oxide, lead phosphate, and lead sulfate). Lead is considered toxic to all organ systems and serves no useful purpose in the body.

Occupational exposure to inorganic lead occurs via inhalation of lead-containing dust and fume and ingestion of lead particles from contact with lead-contaminated surfaces. Exposure may also occur through transfer of lead to the mouth from contaminated hands or cigarettes when careful attention to hygiene, particularly hand washing, is not practiced. In addition to the inhalation and ingestion routes of exposure, lead can be absorbed through the skin, particularly through damaged skin [Filon et al. 2006; Stauber et al. 1994; Sun et al. 2002].

\section{Occupational Exposure Limits for Lead in Air}

In the United States, employers in general industry are required by law to follow the OSHA lead standard [29 CFR 1910.1025]. This standard was established in 1978 and has not yet been updated to reflect the current scientific knowledge regarding the health effects of lead exposure. Under the OSHA standard, the PEL for airborne exposure to lead is $50 \mu \mathrm{g} / \mathrm{m}^{3}$ of air for an 8-hour TWA, with an action level of $30 \mu \mathrm{g} / \mathrm{m}^{3}$ (also an 8-hour TWA). In 2013, the California Department of Public Health (CDPH) recommended that California OSHA lower the PEL for lead to 0.5 to $2.1 \mu \mathrm{g} / \mathrm{m}^{3}$ (8-hour TWA) [Billingsley 2013].

Other guidelines for lead exposure, which are not legally enforceable, are often followed in the United States. Like the OSHA lead standard, these guidelines have also not been updated. The NIOSH REL and ACGIH TLV for lead are $50 \mu \mathrm{g} / \mathrm{m}^{3}$ as an 8-hour work shift [ACGIH 2021; NIOSH 2007]. 


\section{Surface Exposure Limits for Lead}

Neither NIOSH nor OSHA has established surface contamination limits for lead in the workplace. The U.S. Environmental Protection Agency and the U.S. Department of Housing and Urban Development limit lead on surfaces in public buildings and child-occupied housing to less than 40 micrograms of lead per square foot [EPA 1998; HUD 2012]. OSHA requires in its substance-specific standard for lead that all surfaces be maintained as free as practicable of accumulations of lead [29 CFR 1910.1025(h)(1)]. An employer with workplace lead exposures must have regular and effective cleaning of surfaces in areas such as change areas, storage facilities, and lunchroom/eating areas to ensure they are as free as practicable from lead contamination.

\section{Blood Lead Levels}

In most cases, an individual's BLL is a good indication of recent exposure to lead because the half-life of lead (the time interval it takes for the quantity in the body to be reduced by half its initial value) is 1- 2 months [CDC 2013; Lauwerys and Hoet 2001; Moline and Landrigan 2004]. Most lead in the body is stored in the bones, with a half-life of years to decades. Measuring bone lead, however, is primarily done only for research. Elevated zinc protoporphyrin levels have also been used as an indicator of chronic lead intoxication. However, other factors, such as iron deficiency, can cause an elevated zinc protoporphyrin level, so monitoring the BLL over time is more specific for evaluating chronic occupational lead exposure.

The OSHA lead standard mandates medical removal for an employee with a single BLL of $\geq 60 \mu \mathrm{g} / \mathrm{dL}$, or three BLLs averaging $\geq 50 \mu \mathrm{g} / \mathrm{dL}$, and permits return to work once the employee's BLL decreases to $<40 \mu \mathrm{g} / \mathrm{dL}$ [29 CFR 1910.1025]. ACGIH recommends that employee BLLs be controlled to below $20 \mu \mathrm{g} / \mathrm{dL}$, and also designates lead as an animal carcinogen [ACGIH 2021]. CDC recommends removal of pregnant women from lead-exposed work areas when BLLs are $\geq 10 \mu \mathrm{g} / \mathrm{dL}$ [CDC 2010]. In 2013, CDPH recommended that California OSHA keep BLLs below the range of 5 to $10 \mu \mathrm{g} / \mathrm{dL}$ [Billingsley 2013]. In 2015, NIOSH designated $5 \mu \mathrm{g} / \mathrm{dL}$ of whole blood, in a venous blood sample, as the reference BLL for adults [CDC 2015].

\section{Health Effects of Lead}

The OSHA PEL, NIOSH REL, and ACGIH TLV may prevent overt symptoms of lead poisoning, but they do not protect workers from lead's contributions to conditions such as hypertension, renal dysfunction, or reproductive and cognitive effects [Brown-Williams et al. 2009; Holland and Cawthon 2016; Institute of Medicine 2013; Schwartz and Hu 2007; Schwartz and Stewart 2007]. Generally, acute lead poisoning with symptoms has been documented in persons having BLLs above $70 \mu \mathrm{g} / \mathrm{dL}$. These BLLs are rare today in the United States, largely as a result of workplace controls put in place to comply with current OELs. When present, acute lead poisoning can cause a myriad of adverse health effects including abdominal pain, hemolytic anemia, and neuropathy. Lead poisoning has, in very rare cases, progressed to encephalopathy and coma [Moline and Landrigan 2004].

People with chronic lead poisoning, which is more likely at current OELs, may not have symptoms or they may have nonspecific symptoms that may not be recognized as being associated with lead exposure. These symptoms include headache, joint and muscle aches, weakness, fatigue, irritability, depression, constipation, anorexia, and abdominal discomfort [Moline and Landrigan 2004]. 
The National Toxicology Program (NTP) released a monograph on the health effects of low-level lead exposure [NTP 2012]. For adults, the NTP concluded the following about the evidence regarding health effects of lead (Table D1).

Table D1. Evidence regarding health effects of lead in adults

\begin{tabular}{|c|c|c|c|}
\hline Health area & $\begin{array}{l}\text { NTP } \\
\text { conclusion }\end{array}$ & Principal health effects & $\begin{array}{l}\text { Blood lead } \\
\text { evidence }\end{array}$ \\
\hline \multirow[t]{3}{*}{ Neurological } & Sufficient & Increased incidence of essential tremor & Yes, $<10 \mu \mathrm{g} / \mathrm{dL}$ \\
\hline & Limited & $\begin{array}{l}\text { Psychiatric effects, decreased hearing, } \\
\text { decreased cognitive function, increased } \\
\text { incidence of amyotrophic lateral sclerosis }\end{array}$ & Yes, $<10 \mu \mathrm{g} / \mathrm{dL}$ \\
\hline & Limited & Increased incidence of essential tremor & Yes, $<5 \mu \mathrm{g} / \mathrm{dL}$ \\
\hline Immune & Inadequate & & Unclear \\
\hline \multirow[t]{2}{*}{ Cardiovascular } & Sufficient & $\begin{array}{l}\text { Increased blood pressure and } \\
\text { increased risk of hypertension }\end{array}$ & Yes, $<10 \mu \mathrm{g} / \mathrm{dL}$ \\
\hline & Limited & $\begin{array}{l}\text { Increased cardiovascular-related mortality } \\
\text { and electrocardiography abnormalities }\end{array}$ & Yes, $<10 \mu \mathrm{g} / \mathrm{dL}$ \\
\hline Renal & Sufficient & Decreased glomerular filtration rate & Yes, $<5 \mu \mathrm{g} / \mathrm{dL}$ \\
\hline \multirow[t]{6}{*}{ Reproductive } & Sufficient & Women: reduced fetal growth & Yes, $<5 \mu \mathrm{g} / \mathrm{dL}$ \\
\hline & Sufficient & $\begin{array}{l}\text { Men: adverse changes in sperm parameters } \\
\text { and increased time to pregnancy }\end{array}$ & Yes, $\geq 15-20 \mu \mathrm{g} / \mathrm{dL}$ \\
\hline & Limited & $\begin{array}{l}\text { Women: increase in spontaneous abortion } \\
\text { and preterm birth }\end{array}$ & Yes, $<10 \mu \mathrm{g} / \mathrm{dL}$ \\
\hline & Limited & Men: decreased fertility & Yes, $\geq 10 \mu \mathrm{g} / \mathrm{dL}$ \\
\hline & Limited & Men: spontaneous abortion & Yes, $\geq 31 \mu \mathrm{g} / \mathrm{dL}$ \\
\hline & Inadequate & $\begin{array}{l}\text { Women and Men: stillbirth, } \\
\text { endocrine effects, birth defects }\end{array}$ & Unclear \\
\hline
\end{tabular}

Various organizations have assessed the relationship between lead exposure and cancer. According to the Agency for Toxic Substances and Disease Registry [ATSDR 2020] and the NTP [NTP 2016], inorganic lead compounds are reasonably anticipated to cause cancer in humans. The International Agency for Research on Cancer (IARC) classifies inorganic lead as probably carcinogenic to humans [IARC 2006]. According to the American Cancer Society (ACS) [ACS 2011], some studies show a relationship between lead exposure and lung cancer, but these results might be affected by exposure to cigarette smoking and arsenic. Some studies show a relationship between lead and stomach cancer, and these findings are less likely to be affected by the other exposures. The results of studies looking at other cancers, including brain, kidney, bladder, colon, and rectum, are mixed.

\section{Medical Surveillance and Management}

To prevent acute and chronic health effects, a panel of experts convened by the Association of Occupational and Environmental Clinics published guidelines for the management of adult lead exposure [Kosnett et al. 2007]. The panel recommended BLL testing for all lead-exposed employees, regardless of the airborne lead concentration. These recommendations do not apply to pregnant women, who should avoid BLLs $>5 \mu \mathrm{g} / \mathrm{dL}$. Removal from lead exposure should be considered if 
control measures over an extended period do not decrease BLLs to $<10 \mu \mathrm{g} / \mathrm{dL}$, or an employee has a medical condition that would increase the risk of adverse health effects from lead exposure.

NIOSH also supports the health-based medical surveillance and management recommendations summarized in Table D2. This table includes recommendations from an expert panel [Kosnett et al. 2007] and those from CDPH, American College of Occupational and Environmental Medicine (ACOEM), and CSTE to prevent acute and chronic health effects [ACOEM 2010; CDPH 2009, 2019; CSTE 2009, 2013; Holland and Cawthon 2016].

Table D2. Health-based medical surveillance recommendations for lead-exposed employees

\begin{tabular}{|c|c|}
\hline Category of exposure & Recommendations \\
\hline All lead exposed workers & $\begin{array}{l}\text { - Baseline or preplacement medical history and physical examination, } \\
\text { baseline BLL, and serum creatinine }\end{array}$ \\
\hline $\mathrm{BLL}<5 \mu \mathrm{g} / \mathrm{dL}$ & $\begin{array}{l}\text { - BLL monthly for first } 3 \text { months placement, or upon change in task to higher } \\
\text { exposure, then BLL every } 6 \text { months; if BLL increases } \geq 5 \mu \mathrm{g} / \mathrm{dL} \text {, evaluate } \\
\text { exposure and protective measures, and increase monitoring if indicated }\end{array}$ \\
\hline BLL 5-9 $\mu \mathrm{g} / \mathrm{dL}$ & $\begin{array}{l}\text { - } \text { Discuss health risks } \\
\text { - } \text { Minimize exposure } \\
\text { - } \quad \text { BLL monsider removal for pregnancy and certain medical conditions } \\
6 \text { months placement, or upon change in task to higher exposure, then BLL } \\
\text { every } 6 \text { months; if BLL increases } \geq 5 \mu \mathrm{g} / \mathrm{dL} \text {, evaluate exposure and } \\
\text { protective measures, and increase monitoring if indicated }\end{array}$ \\
\hline BLL 10-19 $\mu \mathrm{g} / \mathrm{dL}$ & $\begin{array}{l}\text { - Discuss health risks } \\
\text { - } \text { Decrease exposure } \\
\text { - } \text { Remove from exposure for pregnancy } \\
\text { - } \text { extensider removal for certain medical conditions or BLL } \geq 10 \mu \mathrm{g} / \mathrm{dL} \text { for } \\
\text { - } \text { BLL every } 3 \text { months; evaluate exposure, engineering controls, and } \\
\text { work practices; consider removal. } \\
\text { - Revert to BLL every } 6 \text { months after } 3 \mathrm{BLLs}<10 \mu \mathrm{g} / \mathrm{dL}\end{array}$ \\
\hline BLL 20-29 $\mu \mathrm{g} / \mathrm{dL}$ & $\begin{array}{l}\text { - Remove from exposure for pregnancy } \\
\text { - Remove from exposure if repeat BLL measured in } 4 \text { weeks remains } \\
\geq 20 \mu \mathrm{g} / \mathrm{dL} \\
\text { - } \\
\text { - } \text { Mnnual lead medical exam recommended } \mathrm{BLL} \text { testing } \\
\text { - Consider return to work after } 2 \mathrm{BLLs}<15 \mu \mathrm{g} / \mathrm{dL} \text { a month apart, } \\
\text { then monitor as above }\end{array}$ \\
\hline BLL 30-49 $\mu \mathrm{g} / \mathrm{dL}$ & $\begin{array}{l}\text { - } \text { Remove from exposure } \\
\text { - } \text { Prompt medical evaluation } \\
\text { - } \text { Conthly BLL testing } \\
\text { monitor as above }\end{array}$ \\
\hline BLL 50-79 $\mu \mathrm{g} / \mathrm{dL}$ & $\begin{array}{l}\text { - Remove from exposure } \\
\text { - } \text { Prompt medical evaluation } \\
\text { - Consider chelation with significant symptoms }\end{array}$ \\
\hline $\mathrm{BLL} \geq 80 \mu \mathrm{g} / \mathrm{dL}$ & $\begin{array}{l}\text { - Remove from exposure } \\
\text { - Urgent medical evaluation } \\
\text { - Chelation may be indicated }\end{array}$ \\
\hline
\end{tabular}

Adapted from Kosnett et al. 2007, CSTE 2013, and CDPH 2014 


\section{Take-home Contamination}

Occupational exposures to lead can result in exposures to household members, including children, from take-home contamination. Take-home contamination occurs when lead dust is transferred from the workplace on employees' skin, clothing, shoes, and other personal items to their vehicle and home [CDC 2009, 2012]. CDC considers a BLL in children of $5 \mu \mathrm{g} / \mathrm{dL}$ or higher as a reference level above which public health actions should be initiated and states that no safe BLL in children has been identified [CDC 2013].

The U.S. Congress passed the Workers' Family Protection Act in 1992 (29 U.S.C. 671a). The Act required NIOSH to study take-home contamination from workplace chemicals and substances, including lead. NIOSH found that take-home exposure is a widespread problem [NIOSH 1995]. Workplace measures effective in preventing take-home exposures were (1) reducing exposure in the workplace, (2) changing clothes before going home and leaving soiled clothing at work for laundering, (3) storing street clothes in areas separate from work clothes, (4) showering before leaving work, and (5) prohibiting removal of toxic substances or contaminated items from the workplace. NIOSH noted that preventing take-home exposure is critical because decontaminating homes and vehicles is not always effective. Normal house cleaning and laundry methods are inadequate, and decontamination can expose the people doing the cleaning and laundry. 


\section{Section E: References}

\section{Lead}

ACGIH [2021]. TLVs ${ }^{\circledR}$ and BEIs ${ }^{\circledR}$ : threshold limit values for chemical substances and physical agents and biological exposure indices. Cincinnati, OH: American Conference of Governmental Industrial Hygienists, https://www.acgih.org/tlv-bei-guidelines/policies-procedures-presentations/overview.

ACOEM [2010]. ACOEM provides input to OSHA on key issues facing agency in 2010. Letter to David Michaels, Director of OSHA. Elk Grove Village, IL: American College of Occupational and Environmental Medicine, http:/ $/$ www.acoem.org $/$ Page2Column.aspx?PageID=7392\&id=6676.

ACS [2011]. Lead. Atlanta, GA: American Cancer Society, https://www.cancer.org/cancer/cancercauses/general-info/known-and-probable-human-carcinogens.html.

ATSDR [2020]. Toxicological profile for lead. Atlanta, GA: U.S. Department of Health and Human Services, Agency for Toxic Substances and Disease Registry, https: $/ /$ www.atsdr.cdc.gov/toxprofiles $/$ tp.asp?id=96\&tid=22.

Billingsley KJ [2013]. Letter from K.J. Billingsley, California Department of Public Health, to Juliann Sum, Division of Occupational Safety and Health (Cal/OSHA), California Department of Industrial Relations, September 30.

Brown-Williams H, Lichterman J, Kosnett M [2009]. Indecent exposure: lead puts workers and families at risk. Health Research for Action. University of California, Berkeley. Perspectives 4(1):1-9, http://www.healthresearchforaction.org/sites/default/files/PDF PERSPECTIVES IndecentExp $\% 20$ FNL 0.pdf.

CDC [2009]. Childhood lead poisoning associated with lead dust contamination of family vehicles and child safety seats-Maine, 2008. MMWR 58(32):890-893, https://www.cdc.gov/mmwr/preview/mmwrhtml/mm5832a2.htm.

CDC [2010]. Guidelines for the identification and management of lead exposure in pregnant and lactating women. Atlanta, GA: U.S. Department of Health and Human Services, Centers for Disease Control and Prevention, https://www.cdc.gov/nceh/lead/publications/leadandpregnancy2010.pdf.

CDC [2012]. Take-home lead exposure among children with relatives employed at a battery recycling facility—Puerto Rico, 2011. MMWR 61(47):967-970, https://www.cdc.gov/mmwr/preview/mmwrhtml/mm6147a4.htm.

CDC [2013]. Blood lead levels in children aged 1-5 years—United States, 1999-2010. MMWR 62(13):245-248, https://www.cdc.gov/mmwr/preview/mmwrhtml/mm6213a3.htm.

CDC [2015]. Adult blood lead epidemiology and surveillance (ABLES). Atlanta, GA: U.S. Department of Health and Human Services, Centers for Disease Control and Prevention, http://www.cdc.gov/niosh/topics/ables/description.html.

E-1 
CDC [2016]. National Notifiable Diseases Surveillance System (NNDSS), lead, elevated blood levels 2016 case definition. Atlanta, GA: U.S. Department of Health and Human Services, Centers for Disease Control and Prevention, https://wwwn.cdc.gov/nndss/conditions/lead-elevated-blood-

levels/casedefinition/2016/.

CDPH [2009]. Medical guidelines for the lead-exposed worker. Sacramento, CA: California Department of Public Health, Occupational Lead Poisoning Prevention Program,

https://www.cdph.ca.gov/Programs/CCDPHP/DEODC/OHB/OLPPP/CDPH $\% 20 D$ ocument $\% 20$ Library/medgdln.pdf.

CDPH [2019]. Health-based guidelines for blood lead levels in adults. Sacramento, CA: California Department of Public Health, Occupational Lead Poisoning Prevention Program, https://www.cdph.ca.gov/Programs/CCDPHP/DEODC/OHB/OLPPP/CDPH $\% 20$ Document $\% 20$ Library/AdultMgtGuide.pdf.

CFR [2021]. Code of Federal Regulations. Washington, DC: U.S. Government Printing Office, Office of the Federal Register, https://www.ecfr.gov/cgi-bin/ECFR?page=browse.

CSTE [2009]. Public health reporting and national notification for elevated blood lead levels. CSTE position statement 09-OH-02. Atlanta, GA: Council of State and Territorial Epidemiologists, https://cdn.ymaws.com/www.cste.org/resource/resmgr/PS/09-OH-02.pdf.

CSTE [2013]. Management guidelines for blood lead levels in adults. Atlanta, GA: Council of State and Territorial Epidemiologists,

http://c.ymcdn.com/sites/www.cste.org/resource/resmgr/OccupationalHealth/ManagementGuidelin esforAdult.pdf.

CSTE [2015]. Public health reporting and national notification for elevated blood lead levels. CSTE position statement 15-EH-01. Atlanta, GA: Council of State and Territorial Epidemiologists, https://cdn.ymaws.com/www.cste.org/resource/resmgr/PS1/15-EH-01 revised 12.4.15.pdf.

EPA [1998]. Risk analysis to support standards for lead in paint, dust, and soil. Washington, DC: Environmental Protection Agency, EPA-747-R-097-006, http://www2.epa.gov/lead/riskanalysissupport-standards-lead-paint-dust-and-soil-volume-ichapters-1-7-and-appendix-epa.

Filon FL, Boeniger M, Maina G, Adami G, Spinelli P, Damian A [2006]. Skin absorption of inorganic lead (PbO) and the effect of skin cleansers. J Occup Environ Med 48(7):692-699, https://doi.org/10.1097/01.jom.0000214474.61563.1c.

Holland MG, Cawthon D [2016]. ACOEM position statement: workplace lead exposure. J Occup Environ Med 58(12):371-374, https://doi.org/10.1097/jom.0000000000000928.

HUD [2012]. Guidelines for the evaluation and control of lead-based paint hazards in housing. Washington, DC: Housing and Urban Development, https://www.hud.gov/program offices/healthy homes/lbp/hudguidelines. 
Institute of Medicine [2013]. Potential health risks to DOD firing-range personnel from recurrent lead exposure. Washington, DC: National Academies Press, https://www.ncbi.nlm.nih.gov/books/NBK206966/pdf/Bookshelf NBK206966.pdf.

IARC [2006]. IARC monographs on the evaluation of carcinogenic risks to humans. Inorganic and organic lead compounds. Summary of data reported and evaluation. Vol. 87. Lyon, France: World Health Organization, International Agency for Research on Cancer, http://monographs.iarc.fr/ENG/Monographs/vol87/.

Kosnett MJ, Wedeen RP, Rothenberg SJ, Hipkins KL, Materna BL, Schwartz BS, Hu H, Woolf A [2007]. Recommendations for medical management of adult blood lead exposure. Environ Health Perspect 115(3):463-471, https://doi.org/10.1289/ehp.9784.

Lauwerys RR, Hoet P [2001]. Industrial chemical exposure: guidelines for biological monitoring. 3rd ed. Boca Raton, FL: CRC Press, https://doi.org/10.1201/9781482293838.

Moline JM, Landrigan PJ [2004]. Lead. In: Rosenstock L, Cullen MR, Brodkin CA, Redlich CA, eds. Textbook of clinical occupational and environmental medicine. 2nd ed. Philadelphia, PA: Elsevier Saunders.

NIOSH [1995]. Report to Congress on the workers' home contamination study conducted under the Workers' Family Protection Act (29 U.S.C. 671a). Cincinnati, OH: U.S. Department of Health and Human Services, Centers for Disease Control and Prevention, National Institute for Occupational Safety and Health, DHHS (NIOSH) Publication No. 95-123, http://www.cdc.gov/niosh/docs/95123/.

NIOSH [2007]. NIOSH pocket guide to chemical hazards. Cincinnati, OH: U.S. Department of Health and Human Services, Centers for Disease Control and Prevention, National Institute for Occupational Safety and Health, DHHS (NIOSH) Publication No. 2005-149, http://www.cdc.gov/niosh/npg/.

NTP [2012]. Monograph on the health effects of low-level lead. Research Triangle Park, NC: U.S. Department of Health and Human Services, National Institutes of Health, National Institute of Environmental Health Sciences, National Toxicology Program, https://ntp.niehs.nih.gov/ntp/ohat/lead/final/monographhealtheffectslowlevellead newissn 508.pdf. NTP [2016]. Lead and lead compounds. In: Report on carcinogens. 14th ed. Research Triangle Park, NC: U.S. Department of Health and Human Services, National Institutes of Health, National Institute of Environmental Health Sciences, National Toxicology Program, https://ntp.niehs.nih.gov/ntp/roc/content/profiles/lead.pdf.

Schwartz BS, Hu H [2007]. Adult lead exposure: time for change. Environ Health Perspect 115(3):451454, https://doi.org/10.1289/ehp.9782.

Schwartz BS, Stewart WF [2007]. Lead and cognitive function in adults: a question and answers approach to a review of the evidence for cause, treatment, and prevention. Int Rev Psychiatry 19(6):671-692, https://doi.org/10.1080/09540260701797936. 
Stauber JL, Florence TM, Gulson B, Dale L [1994]. Percutaneous absorption of inorganic lead compounds. Sci Total Environ 145(1-2):55-70, https://doi.org/10.1016/0048-9697(94)90297-6. Sun CC, Wong T'T, Hwang YH, Chao KY, Jee SH, Wang JD [2002]. Percutaneous absorption of inorganic lead compounds. Am Ind Hyg Assoc J 63(5):641-646, https://doi.org/10.1080/15428110208984751. 
This page left intentionally blank 


\section{Delivering on the Nation's promise: Promoting productive workplaces through safety and health research}

Get More Information

Find NIOSH products and get answers to workplace safety and hea lth questions:

1-800-CDC-INFO (1-800-232-4636) | TT: 1-888-232-6348 CDC/NIOSH INFO: cdc.gov/info | cdc.gov/niosh Monthly NIOSH eNews: cdc.gov/niosh/eNews 